\title{
FIELD CONTROL OF LEAF ROT DISEASE OF COCONUT WITH FUNGICIDES
}

\author{
By \\ N. Srinivasan ${ }^{1}$ and M. Gunasekaran ${ }^{1}$
}

\begin{abstract}
SUMMARY
Leaf rot is a disease of fungal complex super imposed on root (wilt) affected coconut palms in India. A field fungicidal control trial on the disease involving contact (indofil M-45, Fytolan) and systemic (Calixin) fungicides was conducted Fungicidal treatments, spraying of Indofil M-45 and pouring of Calixin into axil of spindle, were found beneficial as the disease intensity reduced in newly emerged leaves. However, the extent of disease amelioration by fungicides was marginal to moderate level only. Importance of broad spectrum fungicide(s) and measures of disease protection are outlined.
\end{abstract}

\section{INTRODUCTION}

Coconut leaf rot is a devastating disease superimposed on over $60 \%$ of root (wilt) affected palms in southern districts of Kerala State, India (Radha and Lal, 1968, Srinivasan, 199 1). The early symptoms of the disease is usually manifested in spindle leaves leading to an extensive rotting of tissues; reinfections also occur commonly in emerging spindles bringing about a sharp deterioration of affected palms (Srinivasan and Gunasekaran, 1992). The complex nature of the disease has been described (Menon and Nair, 1951, Srinivasan and Gunasekaran, 1993, 1994; Srinivasan et al., 1995).

Regular application of Bordeaux mixture (Menon arid Nair, 1951; Nair and Radha, 1959) or spraying of copper based fungicides (Anonymous, 1963) was reported beneficial in reducing the disease. Contrasting results have been encountered on application of Bordeaux mixture, Dithane M-45 arid cuman (Anonymous, 1970). Aerial spraying of oil based copper fungicides also lead to no consistent positive effect (Gregory, 1960; Samraj et al., 1966; Anonymous, 1970). Neither complete control of the disease nor prevention of its incidence has been possible (Anonymous, 1982, 1983). Sequential spraying of diseased palms with certain fungicides, perhaps a permutation from earlier measures, is in vogue (Joseph arid Rawther, 1991).

Since leaf rot is of complex nature, disease recurrence common arid amelioration generally difficult, it is imperative more field trials are taken up. In this paper the results emanated from a field fungicidal trial is presented.

\section{MATERIALS AND METHODS}

The leaf rot control experiment was conducted with naturally affected palms in CPCRI Regional Station Farm, Kayangulam for a duration of about three years.

\section{Selection of Palms and Disease Indexing}

Twenty year old palms with clear symptoms were marked. Palmwise quantification of the disease intensity was computed by using an indexing method as given below:

\footnotetext{
${ }^{1}$ Central Plantation Crops Research Institute Regional Station, Kayangulam, Krishnapuram-690 533, Kerala, India.
} 
Disease index (D. 1.) $=\frac{\text { Total Numerical Ratings }}{\text { No.of Leaves x max No. of Categories }} \times 100$

The disease categories with corresponding percent leaf area affected are

$$
\begin{aligned}
& 0: \text { Healthy } \\
& 1: \text { Upto } 25 \% \\
& 2: 26-50 \% \\
& 3: 51-75 \% \\
& 4: 76-100 \%
\end{aligned}
$$
of palms.

Leaves were individually graded and Total Numerical Ratings summed up to arrive the D.I.

\section{Treatment and recording of observations}

The pre-treatment D.I. of palms was comprehended and palms distributed among treatments in such a manner that mean D.I. of treatments are closer as far as possible. The palms were

\begin{tabular}{|c|c|c|c|}
\hline $\begin{array}{l}\text { Treatment } \\
\text { No. }\end{array}$ & Fungicide & $\begin{array}{l}\text { Concentration } \\
\text { Used }(\%) \\
\end{array}$ & $\begin{array}{l}\text { Mode of application } \\
\text { (IL of solution/palm) }\end{array}$ \\
\hline $\mathrm{I}$ & $\begin{array}{c}\text { Calixin } \\
\text { (Tridemorph } 80 \% \text { EC) }\end{array}$ & 0.1 & Spraying onto crown \\
\hline II & -do- & -do- & $\begin{array}{l}\text { Pouring into axil around the } \\
\text { spindle }\end{array}$ \\
\hline III & $\begin{array}{c}\text { Indofil M-45 } \\
\text { (Mancozeb 75\% WP) }\end{array}$ & 0.3 & Spraying onto crown \\
\hline IV & -do- & -do- & $\begin{array}{l}\text { Pouring into axil around the } \\
\text { spindle }\end{array}$ \\
\hline V & $\begin{array}{c}\text { Fytolan (Copper } \\
\text { Oxychloride } 88 \% \\
\text { (W/W) } \\
\text { Control }\end{array}$ & 0.5 & - do- \\
\hline & & & No application of fungicide \\
\hline
\end{tabular}
numbered treatment wise and the youngest leaf (spindle) of each palm was marked with red paint indelibly for follow up, to monitor the disease status of subsequently emerging spindles.

One systemic (Calixin) and two contact (Indofil M-45 and Fytolan) fungicides were used. The treatment details are : 
In addition Calixin $1 \%(1 \mathrm{mi} / \mathrm{I} 00 \mathrm{ml}$ of water) taken in polythene bags was applied to a group of palms through roots at $100 \mathrm{ml}$ solution per palm.

Suspensions of fungicides were prepared afresh in clear water. The schedule of fungicidal application was thrice a year (June, September and January) covering the pre and post monsoon periods. The initial round of application was given in June, 1992. There were 10 replications per treatment comprising five palms each of West Coast Tall and Dwarf $\mathrm{x}$ Tall.

The disease grading of experimental palms were recorded prior to imposition of every schedule. The D.I. for newly emerged leaves (cumulative number of fresh leaves after pre-treatment) and also overall D.I. for palms at every round calculated separately. Trial was continued till ail the leaves in the crown were completely replaced with newly emerged leaves since its start. The data were analyzed for assessing the trend of disease suppression by treatments.

\section{RESULTS AND DISCUSSION}

Leaf rot index of emerged leaves of the whole crown of experimental palms, at different rounds in comparison to pre-treatment D.I., are presented in Tables 1 and 2 respectively.

Leaf rot severity was lesser in Indofil M-45 spraying (1 7.2 - 34.3) with a mean of 25.7 D.I. and Calixin pouring (21.0 - 35.5) with a mean of 27.4 D.I. The disease intensity highest in control (37.4) was on par with other treatments. Between rounds also significant differences were observed. During the first three rounds a gradual reduction in the D.I. was observed but it shot up in the fourth round. Although the disease intensity came down in the next round, there after it was showing a rising trend. In palms under root absorption of Calixin, the D.I. among rounds was higher and the palms continued to decline.

Variation in post treatment D.I. of whole crown of the palms was also noticed. At fifth round of observation there had been a lesser D.I. in experimental palms. Thereafter a steady rise in D.I. set in. At final round of observation when all the leaves in the crown were replaced by newly emerged leaves, the D.I. among treatments was lesser by 5.1 to 10.6 from their corresponding pre-treatments values. Leaf rot suppression was attained at marginal to moderate extent. The extent of disease suppression by fungicidal application, with pre-treatment D.I. as base, was worked out to be $11.3-26.7 \%$ among treatments as on final round. In control palms the D.I. was slightly increased (2.3) and deterioration evident. In root absorption of Calixin also was no perceptible reduction in the D.I.

Earlier works (Menon and Nair, 1951; Nair and Radha, 1959; Anonymous, 1963) revealed general beneficial effect of fungicides in leaf rot control. Results of the present study are in conformity with such reports. Application of Calixin into axil around the spindle/spraying of Indofil M-45 resulted in the reduction of leaf rot among emerged leaves. The limited extent of disease amelioration could be the sequel of complex nature of the disease ( Srinivasan and. Gunasekaran, 1993; Srinivasan et al., 1995), vulnerability of root (wilt) diseased palms (Srinivasan, 1991), performance of fungicides under field conditions etc.

As the foci of infection by the pathogens is in young leaves, specially the spindles (Srinivasan and Gunasekaran, 1992), protective measures of such leaves is of importance. Fungicidal with broad spectrum potential combating predominant pathogens and systemic/eradicant action are likely to be more useful in the disease management. Srinivasan and Gunasekaran (in press) made in vitro assay of certain fungicides against the predominant fungi of leaf rot and deduced one such fungicide, Hexaconazole (Contaf $5 \%$ EC), for possible utility in leaf rot control measures. 


\section{ACKNOWLEDGEMENT}

The authors thank Director, C.P.C.R.I., Kasaragod and Head, Regional Station, Kayangulam for facilities and to Mr. Jacob Mathew Principal Scientist, for data analysis.

\section{REFERENCES}

Anonymous (1 963): Annual Report for 1961-62, Central Coconut Research Station, Kayangulam, pp. 218.

Anonymous (1970) : Annual Report for 1968. Central Coconut Research Station, Kayangulam, pp 37.

Anonymous (1982). Annual Report for 1979. Central Plantation Crops Research Institute, Kasaragod. pp 276.

Anonymous (1983) : Annual Report for 1981. Central Plantation Crops Research Institute, Kasaragod. pp 279.

Gregory, P. J. (1960): Protection of agricultural crop diseases and pests by aerial spraying with reference to coconut. Indian Cocon. J., 14: 323-330.

Joseph, T. and T. S. S. Rawther (1991): Leaf rot disease pp. 81-89. In Coconut root (wilt) disease (Eds. Nair, M.K., K.K.N. Nambiar, P.K. Koshy and N.P. Jayasankar). Monograph series No. 3, CPRCI, Kasaragod, 92 p.

Menon, K. P. V. and U. K. Nair (1 95 1): Scheme for the investigation of the root and leaf diseases of the coconut palms in South India: Consolidated final reports of the work done from $8^{\text {th }}$ March, 1937 to $31^{\text {st }}$ March, 1948. Indian Cocon. J. 5 (1): 5-19.

Nair, U. K. and Radha (1959) : Manuring cum spraying for the control of coconut palm diseases. Proc. $1^{\text {st }}$ Conf. Cocon. Res. Workers, Trivandrum, India, 250-254.

Radha, K. and S. B. Lal (1968): Some observation on the occurrence of leaf rot disease of coconut and associated factors. $3^{\text {rd }}$ Session, FAO Tech. Wkg. Pty. Cocon. Prod. Prot. and Proc. Jogjakarta, 1-5

Samraj, J., P. V. Paily and A. Cheeran ( 1966) : Observation on the aerial application of oil-based fungicide against the leaf rot disease of the coconut palm. Agric. Res. J. Kerala, 4: 67-70.

Srinivasan, N. and M. Gunasekaran (1992) : An appraisal of symptom expression in coconut clue to leaf rot disease. Indian Cocon, J. , 23 (7): 2-6.

SrInivasan, N. and M. Gunasekaran (1 993) : Fungi associated with leaf rot disease of coconut. Indian Cocon. J., 23 (10): 2-7

Srinivasan, N. and M. Gunasekaran (1 994): Identification of Colletotrichum gloeosporioides, Exserghilum rostratum and Gliocladium vermoeseni associated with leaf rot disease of coconut in India. CORD, 10 (1): 34-50

Srinivasan, N., M. Gunasekaran, Rohini Iyer, R. Chandramohanan and M. Kochu Babu (1995): Mycoflora of leaf rot affected coconut palms. Indian Phytopathol. , 48(1): 93-95. 
Table 1. Leaf rot disease (D.I.) of emerged leaves of coconut palms under fungicidal control trial a

\begin{tabular}{|c|c|c|c|c|c|c|c|c|c|c|c|}
\hline \multirow{2}{*}{$\begin{array}{c}\text { Treatment } \\
\text { No. }\end{array}$} & \multirow{2}{*}{ Fungicide } & \multicolumn{10}{|c|}{ D.I. of emerged leaves in different rounds of observation $b$} \\
\hline & & $\begin{array}{l}\text { Sept. } \\
\text { '92 }\end{array}$ & $\begin{array}{l}\text { Jan. } \\
\text { '93 }\end{array}$ & June & Sept & $\begin{array}{l}\text { Jan. } \\
\text { '94 }\end{array}$ & June & Sept. & $\begin{array}{l}\text { Jan. } \\
\text { '95 }\end{array}$ & $\begin{array}{l}\text { Mean } \\
\text { D.I. }\end{array}$ & L.S.D. $(P=0.05)$ \\
\hline I. & Calixin-Spraying & 44 & 37.2 & 26.2 & 41.4 & 29.3 & 34.3 & 31.9 & 36.9 & 35.2 & For treatments: $(T) 5.4$ \\
\hline ॥l. & Indofil M-45- Spraying & 34.3 & 20.9 & 17.2 & 25.4 & 20.4 & 28.2 & 29.9 & 29.1 & 25.7 & \\
\hline III. & Calixin-Pouring & 23 & 24.2 & 21.2 & 35.5 & 21 & 28.1 & 32.8 & 32.4 & 27.4 & Four rounds of Observation: 6.2) 6.2 \\
\hline IV. & Indofil M-45- Pouring & 36 & 30.7 & 37.9 & 42.3 & 32.1 & 38 & 32.8 & 39.5 & 36.2 & Interaction between T \& R: 15.2 \\
\hline \multirow[t]{3}{*}{ V. } & Fytolan-Pouring & 24.2 & 24.7 & 34.1 & 42.1 & 30 & 34.8 & 29 & 33.3 & 31.5 & \\
\hline & Control & 35.0 & 35.7 & 35.5 & 39.8 & 31.6 & 37.5 & 36.2 & 47.5 & 37.4 & \\
\hline & Mean D.I. & 32.8 & 29.1 & 37.8 & 37.8 & 27.4 & 33.5 & 32.1 & 36.5 & & \\
\hline \multicolumn{12}{|c|}{ Observation Trial: } \\
\hline \multicolumn{2}{|c|}{ Calixin - root absorption } & 45.7 & 38.6 & 48.7 & 60.2 & 39.6 & 51.4 & 39.8 & 50.2 & 46.8 & \\
\hline
\end{tabular}

a - means of 10 palms/treatment

$b$ - leaves emerged after the initiation of experiment 
Table 2. Pre and post treatment leaf rot disease indices (D.I.) whole crown of coconut palms under fungicidal control trial a

\begin{tabular}{|c|c|c|c|c|c|c|c|c|c|c|}
\hline \multirow{2}{*}{$\begin{array}{c}\text { Treatment } \\
\text { No. }\end{array}$} & \multirow{2}{*}{ Fungicide } & \multicolumn{9}{|c|}{ D.I. of Palms (whole crown) in pre-treatment and different rounds of observation } \\
\hline & & $\begin{array}{l}\text { Pre-treatment } \\
\text { (June '92) }\end{array}$ & Sept. & Jan. '93 & June & Sept. & Jan. ‘94 & June $^{b}$ & Sept & Jan' ' 95 \\
\hline I. & Calixin-Spraying & 42.2 & 39.9 & 46.4 & 42.3 & 52.7 & 32.5 & 35.0 & 32.2 & 36.9 \\
\hline II. & Indofil M-45-Spraying & 39.7 & 41.1 & 42.1 & 38.8 & 43.0 & 22.0 & 29.5 & 29.8 & 29.1 \\
\hline III. & Calixin-Pouring & 40.2 & 36.2 & 45.2 & 38.5 & 46.2 & 22.3 & 29.2 & 32.9 & 32.4 \\
\hline IV. & Indofil M-45-Pouring & 44.6 & 47.7 & 48.2 & 53.4 & 55.1 & 34.0 & 40.4 & 32.9 & 39.5 \\
\hline \multirow[t]{2}{*}{ V. } & Fytolan-Pouring & 39.7 & 39.1 & 44.9 & 48.7 & 53.4 & 30.1 & 37.6 & 29.8 & 33.3 \\
\hline & Control & 45.2 & 47.3 & 50.5 & 51.4 & 53.3 & 37.7 & 38.8 & 36.3 & 47.5 \\
\hline \multicolumn{11}{|c|}{ Observation Trial: } \\
\hline \multicolumn{2}{|c|}{ Calixin-root absorption } & 57.2 & 59.7 & 56.3 & 56.4 & 66.8 & 38.7 & 53.2 & 39.9 & 50.2 \\
\hline
\end{tabular}

a - means of 10 palms/treatment

$\mathrm{b}$ - Analysed using the analysis of covariance technique taking the pre-treatment value as the covariate: Difference of D.I. no significant. 